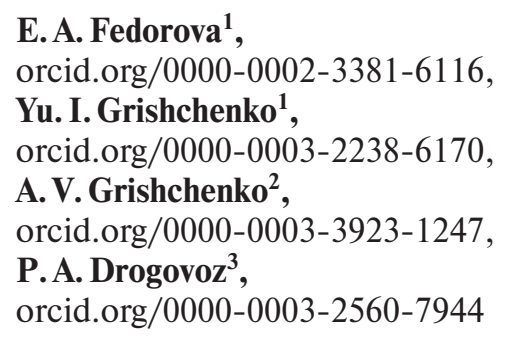

1 - Financial University under the Government of the Russian Federation, Moscow, Russian Federation, e-mail: ecolena@mail.ru

2 - MIREA-Russian Technological University, Moscow, Russian Federation

3 - BMSTU-Bauman Moscow State Technical University, Moscow, Russian Federation

\title{
EVALUATION OF INFORMATION DISCLOSURE IN ANNUAL REPORTS OF EXTRACTIVE INDUSTRY COMPANIES
}

Purpose. To assess how public annual reports of Russian extractive industry issuers comply with the requirements for disclosure of information. To examine how the introduction of Corporate Governance Code affects the level of information disclosure in extractive industries.

Methodology. The paper presents the dictionary compiled by the authors using text analysis. The dictionary contains 186 terms which are to be disclosed in compliance with the requirements of Russian law. To evaluate the level of information disclosure in annual reports of extractive industry issuers, the authors calculate mandatory disclosure index.

Findings. In this work, based on the standards for disclosing non-financial information in public annual reports of issuers, the following results were obtained:

1. On the basis of regulatory enactments, key terms are identified that are subject to mandatory disclosure in the annual report of the issuer.

2. A methodology is developed for assessing the level of disclosure of non-financial information on the selected blocks based on textual analysis.

3. Assessment of information disclosure in the public annual reports of mining companies in accordance with the legislation of the Russian Federation was carried out. The rating of information disclosure has been built.

Originality. The authors are the first to assess mandatory disclosure in 120 public annual reports of 12 largest extractive industry companies whose shares were traded in Moscow Exchange from 2009 to 2018. On the basis of regulatory enactments, key terms are identified that are subject to mandatory disclosure in the annual report of the issuer. A methodology is developed for assessing the level of disclosure of non-financial information on the selected blocks based on textual analysis. The assessment of information disclosure in the public annual reports of mining companies in accordance with the legislation of the Russian Federation was carried out.

Practical value. The created library in Package R enables to evaluate disclosure of information in public annual reports for any period.

Keywords: annual report, non-financial reports, extractive industry, text analysis

Introduction. In terms of globalization of stock market, transformation of Russian economy and enhanced economic policy, the principal aim of the government is to increase transparency and quality of disclosure of non-financial information as well as to promote international collaboration in this field. Public annual reports of extractive industry companies along with other reports on economic issues include non-financial information (strategies, features of industry, risks, dividend policy, management principles, and so on). The Bank of Russia Board of Directors approved the Corporate Governance Code on March 21 ${ }^{\text {st }}$, 2014. In addition, based on the Concept of Public Non-financial Reporting the Ministry of Economic Development of the Russian Federation introduced a draft federal law "On Public Non-Financial Reporting”. Next, Ordinance "On Disclosing Information by Securities Issuers" (by the Bank of Russia, dated 30 December 2014 No. 454-P) clarifies the order, form, deadlines, the scope of mandatory financial and non-financial information to be disclosed in a public annual report.

The current experience and regulatory requirements for public annual reports of extractive industry companies indicate the need to examine issuers' reports and identify to what extent their mandatory disclosure complies with the requirements of Russian laws. The paper aims to assess how public annual reports of Russian extractive industry issuers meet the requirements for disclosure of information; to evaluate how the level of information disclosure is related to investment attractiveness of companies. This research is different from others as:

1. So far the assessment of level of mandatory disclosure in public annual reports has not been the focus of any research,

(C) Fedorova E.A., Grishchenko Yu.I., Grishchenko A.V., Drogovoz P.A., 2021 not only on extractive industries, but also on any other industries.

2. The authors devise a method to evaluate the level of mandatory disclosure in public annual reports of extractive industry companies. It can be presented as a library in Package $\mathrm{R}$ and used to evaluate disclosure of information in public annual reports for any periods.

Literature review. A Russian public annual report of an issuer is an integrated report prepared in compliance with local legal documents of the company regulating public reporting as well as Russian and international requirements for corporate reporting. At the same time, a part of the report is compiled based on regulations adopted by the Bank of Russia. In most cases the second half of the report follows the order of disclosure of non-financial information as it is common throughout the world.

Statement of the task. Recent studies, both Russian and western, put a special emphasis on disclosure of information about corporate social responsibility, environmental responsibility, charity, innovations and others. Foreign researchers regard voluntary disclosure as any kind of financial and non-financial information disclosed by a company's management in addition to mandatory information [1]. The evaluation of significant non-financial information can be quite different, so the disclosure of non-financial information has become the topic of a lively debate for Russian companies. That is the reason why we propose a number of hypotheses.

$H 1$. The majority of extractive industry issuers fulfil the requirements for mandatory disclosure in public annual reports.

Under Russian law information about an issuer's performance that should be included in public annual report is regulated and is to comply with the requirements imposed in article 

2014 No. 454-P). Thus, the annual report of an extractive industry issuer is to provide the following information: industry review and the position of the issuer, information on securities and dividend policy, information on governing and controlling bodies, strategy and long-term development program, and so on. In addition to these requirements, the Information Letter from the Bank of Russia No. IN-06-52/8 dated February $17^{\text {th }}$, 2016 provides recommendations on disclosure of information in the annual report of a public joint-stock company in compliance with the principles of the Corporate Governance Code.

H 2. The introduction of the Corporate Governance Code in Russia has affected the level of mandatory disclosure of non-financial information in annual reports of extractive industry issuers.

Public non-financial reporting is one of the most significant resources of information. Based on it, decisions about fulfilment of strategic goals can be made on the federal level. To enhance investment attractiveness of Russian issuers, to improve business efficiency, to provide their long-term and sustainable development the Bank of Russia Board of Directors approved the Corporate Governance Code on March 21 ${ }^{\text {st }}$, 2014. So, our hypothesis is based on the fact that introduction of the Corporate Governance Code in Russia made a contribution to the growing level of non-financial information disclosure. As a result, the level of non-financial information disclosure in annual reports of extractive industry issuers has risen considerably since 2014-2015.

Disclosure of non-financial information in annual reports of Russian issuers is a strategic tool which improves the collaboration between companies and other interested parties. For instance, the study conducted by EY [2] shows that nonfinancial information is significant for investors: $97 \%$ of them admitted that they used such reports while making investment decisions. Russian issuers voluntarily use foreign experience of non-financial information disclosure which is based on the Global Reporting Initiative. The largest (by market capitalization) mining export-oriented companies have been publishing non-financial reports since 2008 (Norilsk Nickel, Lukoil, Alrosa, Polyus, Gazprom and others).

Table 1 summarizes the findings of Russian and foreign studies demonstrating the effect which non-financial information disclosure has on the issuer's performance.

The data of Table 1 provide evidence that there is a relationship between non-financial disclosure and investment attractiveness of a company:

- Tobin's Q, Return on equity (ROE) [3];

- Tobin's Q, leverage, Return on assets (ROA), dividends [4];

- return ratios, capital-output ratio [2];

- Return on assets (ROA), Return on investment (ROI), leverage [5];

- capitalization, stock market index [6];

- share price [7].

The majority of researchers argue that the level of non-financial disclosure in public annual reports is to meet the regulated requirements and satisfy the needs of investors to assess investment attractiveness. Disclosure of non-financial information in annual reports makes a huge contribution to information transparency and is significant for the world economy $[8,9]$. A large number of studies $[4,10,11]$ indicate that stakeholders tend to regard non-financial information as a sufficient source to meet their information needs. The Russian Concept for the Development of Public Non-Financial reporting states that "public non-financial reporting is a set of information and indicators showing aims, methods and performance of companies in any issues related to corporate social responsibility and sustainable development including the minimum range of mandatory indicators". According to auditing organizations EY [12] and KPMG [13], non-financial information specifies

The evaluation of the impact of non-financial information disclosure on the issuer's performance in Russian and foreign studies

\begin{tabular}{|l|l|}
\hline \multicolumn{1}{|c|}{ Authors } & \multicolumn{1}{c|}{ Findings } \\
\hline $\begin{array}{l}\text { M. Waleed } \\
(2020)\end{array}$ & $\begin{array}{l}\text { The authors reveal that transparency and } \\
\text { disclosure have an impact on firms' performance }\end{array}$ \\
\hline $\begin{array}{l}\text { H. Lu } \\
(2019)\end{array}$ & $\begin{array}{l}\text { The authors show that disclosures of } \\
\text { non-financial information facilitate the flow of } \\
\text { funds from investors to the firms }\end{array}$ \\
\hline $\begin{array}{l}\text { E. Platonova } \\
(2018)\end{array}$ & $\begin{array}{l}\text { The findings indicate that there is a significant } \\
\text { positive relationship between corporate social } \\
\text { responsibility disclosure and the financial } \\
\text { performance of Islamic banks }\end{array}$ \\
\hline $\begin{array}{l}\text { D. Gulin } \\
(2018)\end{array}$ & $\begin{array}{l}\text { Non-financial information is more significant } \\
\text { for investors and other parties than mandatory } \\
\text { financial reports }\end{array}$ \\
\hline $\begin{array}{l}\text { O. Mosesa } \\
\text { (2018) }\end{array}$ & $\begin{array}{l}\text { The authors test for market reaction to the } \\
\text { initial disclosure of non-financial information }\end{array}$ \\
\hline $\begin{array}{l}\text { E. N.Feokistova } \\
(2017)\end{array}$ & $\begin{array}{l}\text { The offered "National Corporate Governance } \\
\text { Index-2016" reflects the extent to which } \\
\text { companies comply with the principles of the } \\
\text { National Corporate Governance Code and } \\
\text { depends on capitalization and listing levels of } \\
\text { companies }\end{array}$ \\
\hline $\begin{array}{l}\text { M. Klerk } \\
\text { (2015) }\end{array}$ & $\begin{array}{l}\text { The paper examines the association between } \\
\text { share prices and the level of corporate social } \\
\text { responsibility disclosure of large UK companies }\end{array}$ \\
\hline
\end{tabular}

the business model of a company, influences its investment attractiveness and is to satisfy the growing expectations of investors. Therefore, annual non-financial reporting must be a credible, full, reliable and unbiased source providing information about the extractive industry issuer. This kind of information is supposed to help the investor to evaluate the issuer's performance in the long term and to find an appropriate investment strategy.

Methods. Currently there is a wide range of approaches to non-financial disclosure. Various dictionaries are available in foreign sources: dictionaries on corporate social responsibility, economic and social value orientation, forecasting and financial dictionaries and others. However, there are no similar dictionaries in the Russian language which could help to evaluate mandatory disclosure in annual reports regulated by the Bank of Russia. Based on the above mentioned legal documents, we determine the key terms which an issuer is obliged to disclose in its annual report. Table 2 presents the main groups of terms and provisions of the annual report on which the authors' dictionary is based. To compile this dictionary we take 186 terms which under the Russian law are to be disclosed. We classify them into 8 groups: company information, securities and dividend policy, information on transactions, governing bodies, corporate governance (principles), controlling bodies, risk management, others, mandatory disclosure.

After generalizing the main terms according to legal acts of the Bank of Russia we examine how they are used in non-financial reporting. To find all the word forms in a certain text two methods are usually used: stemming and lemmatization. Stemming is a process of reducing inflection in words to their root forms. Lemmatization is a process of reducing the inflected words and returning the base of a word which is known as a lemma. If one lemmatizes a phrase for search as well as all the words of the text, the problem of grammatical forms can be solved. However, it is impossible to completely eliminate ambiguity due to a range of homonymic forms. For instance, the Russian word "politiki" can be the form not only of a word "politik" (=politician) but also of a word "politika" (=policy) 
Main groups of terms and provisions used for the authors' dictionary

\begin{tabular}{|c|c|}
\hline $\begin{array}{l}\text { Provisions of legal acts used for } \\
\text { the authors' dictionary }\end{array}$ & $\begin{array}{l}\text { Terms (excerpts from the } \\
\text { dictionary) }\end{array}$ \\
\hline \multicolumn{2}{|c|}{ A1. Company's performance } \\
\hline volume of used energy resource & petrol, water, electrical energy \\
\hline $\begin{array}{l}\text { Board of Directors' report on } \\
\text { priority business areas }\end{array}$ & $\begin{array}{l}\text { investment program, } \\
\text { performance results }\end{array}$ \\
\hline prospective development & $\begin{array}{l}\text { mission, strategic development, } \\
\text { forecast }\end{array}$ \\
\hline position in the industry & $\begin{array}{l}\text { sales revenue, results of the } \\
\text { year, company today, industry } \\
\text { overview }\end{array}$ \\
\hline priority business areas & areas, business lines, facility \\
\hline \multicolumn{2}{|c|}{ A2. Securities and dividend policy } \\
\hline $\begin{array}{l}\text { shareholders and relations with } \\
\text { shareholders }\end{array}$ & $\begin{array}{l}\text { equity shareholders, share } \\
\text { buybacks }\end{array}$ \\
\hline $\begin{array}{l}\text { report on dividend payout on } \\
\text { shares (accrued) }\end{array}$ & $\begin{array}{l}\text { total dividends, paid dividends, } \\
\text { payout date, announcement } \\
\text { date, dividend yield }\end{array}$ \\
\hline \multicolumn{2}{|c|}{ A3. Transactions } \\
\hline list of major transactions & major transactions \\
\hline $\begin{array}{l}\text { list of interested party } \\
\text { transactions }\end{array}$ & interested party transactions \\
\hline \multicolumn{2}{|c|}{ A4. Governing bodies } \\
\hline $\begin{array}{l}\text { policy of remuneration of } \\
\text { Board of Directors members }\end{array}$ & $\begin{array}{l}\text { types of remuneration, } \\
\text { monetary compensation }\end{array}$ \\
\hline $\begin{array}{l}\text { amount of all remuneration } \\
\text { types, salary of governing } \\
\text { bodies' members }\end{array}$ & $\begin{array}{l}\text { remuneration of management, } \\
\text { remuneration for service on a } \\
\text { governing body, remuneration } \\
\text { of executives }\end{array}$ \\
\hline $\begin{array}{l}\text { information about a sole } \\
\text { executive body, short biography, } \\
\text { his/her share in charter capital }\end{array}$ & $\begin{array}{l}\text { chief executive officer, year of } \\
\text { birth, date of birth, chairman, } \\
\text { president, born, management } \\
\text { company }\end{array}$ \\
\hline $\begin{array}{l}\text { information about members of } \\
\text { Board of Directors (supervisory } \\
\text { board) including their short } \\
\text { biographies, their share in } \\
\text { charter capital, their share of } \\
\text { common stocks }\end{array}$ & $\begin{array}{l}\text { biographies of Board of } \\
\text { Directors' members, ownership } \\
\text { of shares by members of Board } \\
\text { of Directors, share in charter } \\
\text { capital, share of Board of } \\
\text { Directors' members in charter } \\
\text { capital, short biography }\end{array}$ \\
\hline $\begin{array}{l}\text { transactions with shares by } \\
\text { members of Board of Directors } \\
\text { (supervisory board) on } \\
\text { purchase or disposal of shares }\end{array}$ & $\begin{array}{l}\text { disposal of shares by members, } \\
\text { purchase of shares by members, } \\
\text { sale of shares by members, } \\
\text { information about transactions }\end{array}$ \\
\hline $\begin{array}{l}\text { composition of Board of } \\
\text { Directors (supervisory board) }\end{array}$ & $\begin{array}{l}\text { changes in composition of } \\
\text { Board of Directors, composition } \\
\text { of Board of Directors }\end{array}$ \\
\hline \multicolumn{2}{|c|}{ A5. Corporate governance (principles) } \\
\hline Corporate Governance Code & Corporate Governance Code \\
\hline corporate secretary & $\begin{array}{l}\text { corporate secretary, secretary of } \\
\text { Board of Directors }\end{array}$ \\
\hline $\begin{array}{l}\text { principles of corporate } \\
\text { governance }\end{array}$ & $\begin{array}{l}\text { principles of corporate } \\
\text { governance }\end{array}$ \\
\hline $\begin{array}{l}\text { information (report) about } \\
\text { compliance with principles and } \\
\text { recommendations of the } \\
\text { Corporate Governance Code } \\
\text { set out by the Bank of Russia }\end{array}$ & $\begin{array}{l}\text { key principles and } \\
\text { recommendations of the Code, } \\
\text { report on compliance with the } \\
\text { principles, report on compliance } \\
\text { with the principles and } \\
\text { recommendations of the Code }\end{array}$ \\
\hline
\end{tabular}

\begin{tabular}{|c|c|}
\hline $\begin{array}{l}\text { Provisions of legal acts used for } \\
\text { the authors' dictionary }\end{array}$ & $\begin{array}{l}\text { Terms (excerpts from the } \\
\text { dictionary) }\end{array}$ \\
\hline \multicolumn{2}{|c|}{ A6. Controlling bodies } \\
\hline internal audit & $\begin{array}{l}\text { internal audit, internal audit } \\
\text { department, audit committee, } \\
\text { report of the audit committee }\end{array}$ \\
\hline audit commission & audit commission \\
\hline $\begin{array}{l}\text { risk management and internal } \\
\text { control system }\end{array}$ & $\begin{array}{l}\text { internal control, corporate } \\
\text { insurance }\end{array}$ \\
\hline \multicolumn{2}{|c|}{ A7. Risk management } \\
\hline $\begin{array}{l}\text { description of key risk factors, } \\
\text { identified for the company }\end{array}$ & $\begin{array}{l}\text { major risks, significant risks, } \\
\text { risk factor }\end{array}$ \\
\hline \multirow{2}{*}{$\begin{array}{l}\text { risks related to company } \\
\text { performance }\end{array}$} & reputational risk, competitive risk \\
\hline & $\begin{array}{l}\text { risk of reputational damage, risk } \\
\text { of improper performance }\end{array}$ \\
\hline market risks & price changes, operational risks \\
\hline regulatory risks & regulatory risk, regulatory risks \\
\hline national and regional risks & $\begin{array}{l}\text { political situation, regional } \\
\text { risks, sanctions }\end{array}$ \\
\hline financial risks & $\begin{array}{l}\text { currency risks, liquidity risks, } \\
\text { foreign exchange risks }\end{array}$ \\
\hline strategic risks & strategic risks \\
\hline \multicolumn{2}{|c|}{ A8. Others, mandatory disclosure } \\
\hline company policy & $\begin{array}{l}\text { availability of data, } \\
\text { informational transparency }\end{array}$ \\
\hline $\begin{array}{l}\text { disclosure of information about } \\
\text { the company, informational } \\
\text { transparency }\end{array}$ & $\begin{array}{l}\text { information policy, disclosure } \\
\text { of information }\end{array}$ \\
\hline $\begin{array}{l}\text { information about approval of } \\
\text { annual report }\end{array}$ & $\begin{array}{l}\text { annual report is approved, } \\
\text { approved by }\end{array}$ \\
\hline corporate activities & $\begin{array}{l}\text { reorganization, significant } \\
\text { transactions }\end{array}$ \\
\hline
\end{tabular}

("investment policy"). It makes automatic lemmatization more difficult. Instead, we decide not to modify the text, but to search for all possible grammatical forms of the terms. The term is broken down into 2 words and for each of them we find a lemma and all its grammatical forms. To do it we use the dictionary OpenCorpora.

Calculation of term frequency in the authors' dictionary can be described as follows:

Mandatory disclosure index $(M D I)=A 1$. Company's performance + A2. Securities and dividend policy + A3. Transactions $+A 4$. Governing bodies + A5. Corporate governance (principles) $+A 6$. Controlling bodies + A7. Risk management + A8. Others, mandatory disclosure.

Data analysis and results. The research sample is made of 120 annual reports (for 10 years) of issuers - 12 Russian companies of extractive industry whose shares are traded in Moscow Exchange: Alrosa, Bashneft, Gazprom, Gazprom Neft, Lukoil, Mechel, Novatek, Nornickel, Polyus, Severstal, Surgutneftegas, Tatneft.

To evaluate the level of mandatary disclosure by Russian companies we calculate mandatory disclosure index (MDI) for 2009-2018.

Fig. 1 illustrates MDI on all groups of terms for 2009-2018. As can be seen, there is a growth of MDI. Moreover, frequency rises dramatically from 2015 and in 2018 exceeds 13000 occurrences.

Next, we examine frequency of terms according to their groups for 10 years. Figures below demonstrate that since 2015 there has been a rapid rise in frequency of terms related to principles of corporate governance, controlling bodies, risk man- 


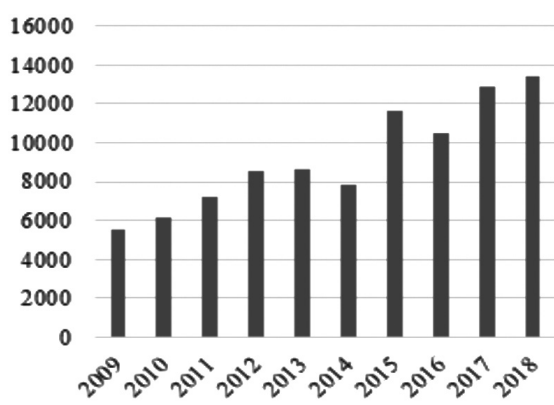

Fig. 1. Mandatory disclosure index in annual reports of 12 extractive industry issuers for 2009-2018

agement and other mandatory information (major corporate activities, information policy, and others). These findings show that growth of frequency is greatly affected by the introduction of the Corporate Governance Code in Russia approved by the Letter of the Bank of Russia on April 10 ${ }^{\text {th }}, 2014$ No. 06-52/2463.

Based on the calculated mandatory disclosure index for 2018, we rank the extractive industry companies (Table 3 ).

The first place is taken by the company "Nornickel" - the frequency for 2018 is 2128 terms. It is followed by "Tatneft" 1627 terms. The third rank belongs to "Gazprom Neft" - 1577 terms. Our findings show that all annual reports of extractive industry issuers contain minimal number of terms (word forms).

Now we consider the case of mandatory information disclosure in annual report of the company "Alrosa". "Alrosa" is the world leader in diamond mining. Its annual report for 2018 includes 260 pages. According to our ranking based on man-

A4. Governing bodies
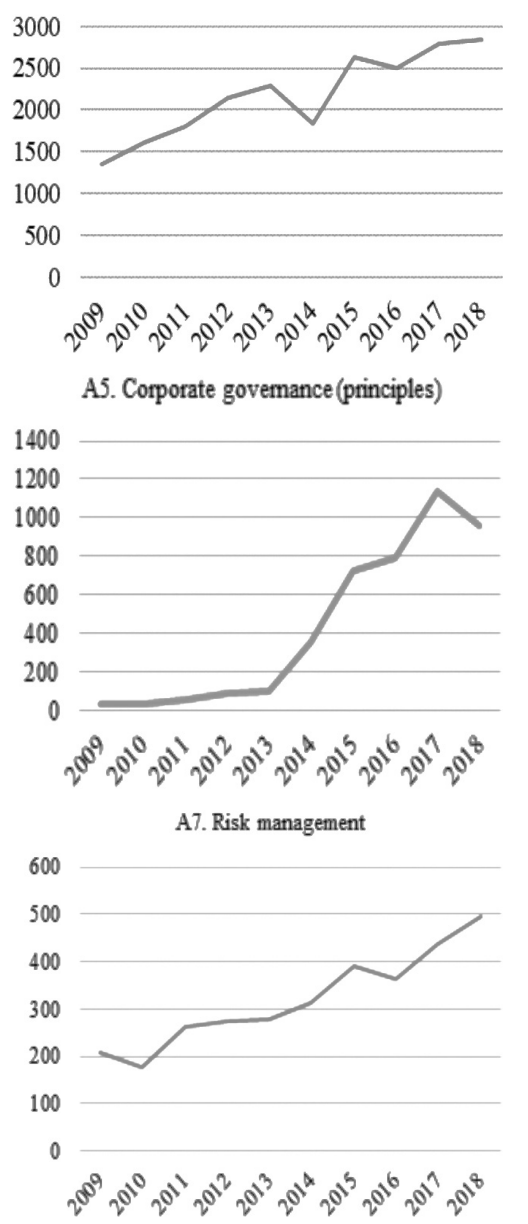

Fig. 2. Frequency of terms according to their groups in annual reports of extractive industry issuers for 10 years
Table 3

Ranking of companies according to Mandatory disclosure index in annual reports of issuers for 2018(terms)

\begin{tabular}{|c|l|c|}
\hline Rank & \multicolumn{1}{|c|}{ Short name } & MDI \\
\hline 1 & Nornikel & 2128 \\
\hline 2 & Tatneft & 1627 \\
\hline 3 & Lukoil & 1577 \\
\hline 4 & Gazprom Neft & 1566 \\
\hline 5 & Alrosa & 1376 \\
\hline 6 & Polyus & 999 \\
\hline 7 & Gazprom & 991 \\
\hline 8 & Bashneft & 869 \\
\hline 9 & Novatek & 710 \\
\hline 10 & Severstal & 699 \\
\hline 11 & Surgutneftegas & 421 \\
\hline 12 & Mechel & 419 \\
\hline
\end{tabular}

datory disclosure index the company holds the $8^{\text {th }}$ position.

The term used in the annual report most frequently is "chairman". This term belongs to the group of words related to governing bodies (A4). It is used 130 times. The second position is held by the word form "risk management" (from the group "controlling bodies" (A6) - 127 occurrences. These findings indicate that the company "Alrosa" discloses information on risk management in a quite detailed way. For example, the report contains the following information: "risk management covers all business functions ...; all subdivisions are responsible for risk management; risk management is a systemic process ...". The term "capital" is included into the group "securities and dividend policy" (A2), it is used 55 times. The least frequently used term is "sanction" (the group "risk management (A7). Thus, in its report the company puts an emphasis on the influence of sanctions on the performance of the company and Russian economy.

The authors suppose that when the mandatory disclosure index (MDI) is lower than the minimal level (186 terms), the further research on annual reports is needed. It will enable to identify the reasons why the issuers do not disclose information which is to be disclosed in compliance with the regulatory requirements.

To increase the rate and sustainability of economic growth, investment attractiveness of extractive industry issuers and to enhance information transparency the authors come to the following conclusions:

- on the whole, companies of extractive industry disclose mandatory non-financial information in their public annual reports;

- as a rule, public annual reports contain detailed information on company performance, financial results, strategic development, corporate governance, and so on;

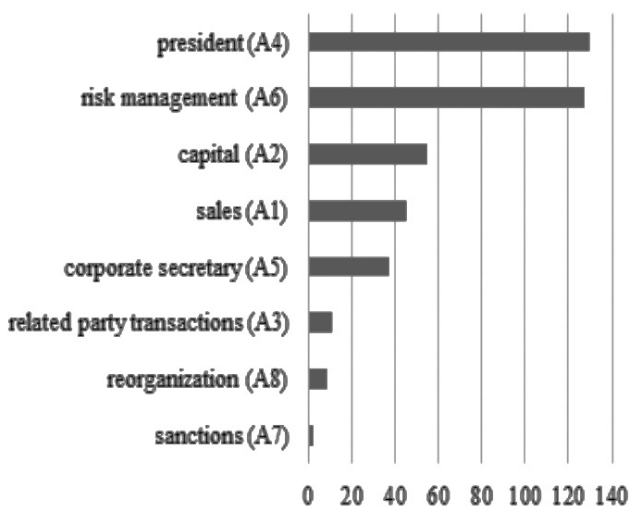

Fig. 3. Terms with the highest frequency (in its group) disclosed in the annual report of "Alrosa" company for 2018 
- introduction of the Corporate Governance Code in Russia in 2014 had a positive impact on the level of non-financial disclosure.

Conclusion. The study evaluated disclosure of mandatory information in public annual reports in compliance with the Russian law. To examine the level of mandatory disclosure by the companies of extractive industry we calculated Mandatory disclosure index (MDI). The overall results indicate that all companies of extractive industry studied tend to meet the requirements for mandatory disclosure in annual reports. Moreover, the level of mandatory disclosure is rising every year. Our findings also revealed that the major contributor to the rising level of mandatory disclosure was the introduction of the Corporate Governance Code in Russia in 2014.

These results can be useful for investors and other users of public annual reports. In addition, we recommend the stock market regulator to employ the developed method for evaluating the level of non-financial information disclosure using text analysis. This method can help to specify legal requirements for the level of mandatory disclosure.

\section{References.}

1. Dhaliwal, D., Li, O., Tsang, A., \& Yang, Y. (2017). Voluntary nonfinancial disclosure and cost of equity capital: The initiation of corporate social responsibility reporting. The Accounting Review, 59-100. https://doi.org/10.1016/i.dss.2015.02.018.

2. EY research: environment, social and governance (ESG) information as well as non-financial reporting have a significant effect on investment decision-making (2019). Retrieved from http://csrjournal.com/31292issledovanie-ey-ekologicheskaya-socialnaya-i-upravlencheskayaesg-informaciya-a-takzhe-dannye-nefinansovoj-otchetnosti-imeyutbolshoe-vliyanie-na-prinyatie-reshenij-investorami.html.

3. Waleed, M., Mohammed, H., Mosab, I., \& Najib, H. (2020). The impact of corporate governance on financial performance of Indian and GCC listed firms: An empirical investigation. Research in International Business and Finance, Article 101083. https://doi.org/10.1016/j. ribaf.2019.101083.

4. Lu, H. (2019). Does Disclosure of Non Financial Statement Information Reduce Firms Propensity to Under-Invest? Retrieved from https:// about.jstor.org/terms/.

5. Rezaee, Z., \& Tuob, L. (2017). Voluntary disclosure of non-financial information and its association with sustainability performance. $A d$ vances in Accounting, 47-59. https://doi.org/10.1016/j.adiac.2017.08.001. 6. Feoktistova, E., Alenicheva, L., Kopylova, G., Ozeryanskaya, M., Purtova, D., \& Khonyakova, N. (2019). Analytical review of corporate non-financial reports: 2017-2018. Retrieved from https://media.rspp. ru/document/1/f/6/f6e6f97287df39e326d6b2d236b459b1.pdf.

7. Klerk, M., Villiers, C., \& Staden, C. (2015). The influence of corporate social responsibility disclosure on share prices Evidence from the United Kingdom. Pacific Accounting Review, 208-228. https://doi. org/10.1108/PAR-05-2013-0047.

8. Yingjun, L., \& Abeysekera, I. (2014). Stakeholders power, corporate characteristics, and social and environmental disclosure: Evidence from China. Journal of Cleaner Production, 426-436. https:// doi.org/10.1016/i.jclepro.2013.10.005.

9. Maroun, W. (2017). Assuring the integrated report: Insights and recommendations from auditors and preparers. The British Accounting Review, 329-346. https://doi.org/10.1016/j.bar.2017.03.003.

10. Gulin, D., Hladika, M., \& Mićin, M. (2018). Disclosure of Nonfinancial Information: The Case of Croatian Listed Companies. Consumer Behavior, Organizational Strategy and Financial Economics, 159-175. 11. Mosesa, O. (2018). What is the economic value of the Extractive Industries Transparency Initiative (EITI) information disclosure. Journal of Contemporary Accounting \& Economics, 216-233. https:// doi.org/10.1016/J.JCAE.2018.05.003.

12. Enhancing investment attractiveness by a report combining financial as well as non-financial information (2019). Retrieved from https:// www.ey.com/ru/ru/services/specialty-services/climate-change-andsustainability-services/integrated-reporting---overview.

13. KPMG: corporate reporting and disclosure of non-financial information (2019). Retrieved from https://home.kpmg/content/dam/kpmg/ $\mathrm{ru} / \mathrm{pdf} / 2018 / 10 / \mathrm{ru}$-ru-corporate-reporting-and-non-financial-information.pdf.

14. Platonova, E., Asutay, M., Dixon, R., \& Mohammad, S. (2018). The Impact of Corporate Social Responsibility Disclosure on Finan- cial Performance: Evidence from the GCC Islamic Banking Sector. The Impact of Corporate Social Responsibility Disclosure on Financial Performance: Evidence from the GCC Islamic Banking Sector, 451-471. https://doi.org/10.1007/s10551-016-3229-0.

15. Enhancing investment attractiveness by a report combining financial as well as non-financial information (2019). Retrieved from https:// www.ey.com/ru/ru/services/specialty-services/climate-change-andsustainability-services/integrated-reporting---overview.

16. Bank of Russia Ordinance (2014). On Disclosing Information by the Issuers of Issue-Grade Securities. Retrieved from https://cbr.ru/publ/ Vestnik/ves15030618-19.pdf.

17. Order of the Government of the Russian Federation (2017). On approval of the Concept for the Development of Public Non-Financial Reporting and Action Plan for its Implementation. Retrieved from http:// www.consultant.ru/document/cons_doc_LAW_216631/.

\section{Оцінка розкриття інформації в річному звіті компанії добувної промисловості}

\section{Е.А. Федорова ${ }^{1}$, Ю. І. Грищенко ${ }^{1}$, А. В. Грищенко ${ }^{2}$, П. А. Дроговоз ${ }^{3}$}

1 - Фінансовий університет при Уряді Російської Федераціï, м. Москва, Російська Федерація, e-mail: ecolena@mail.ru 2 - МIPЕА - Російський технологічний університет, м. Москва, Російська Федерація

3 - МДТУ імені Баумана, м. Москва, Російська Федерація

Мета. Оцінити дотримання вимог щодо розкриття інформації в публічних річних звітах російських емітентів видобувної промисловості. Визначити вплив уведення Кодексу корпоративного управління на рівень розкриття інформації компаній видобувної промисловості.

Методика. У роботі представлений авторський словник, розроблений на основі текстового аналізу, що включає 186 термінів, розкриття яких обумовлено вимогами російського законодавства. Для оцінки ступеня розкриття інформації в річних звітах емітентів видобувної промисловості авторами розрахований індекс розкриття обов’язкової інформації.

Результати. У даній роботі, на основі стандартів розкриття фінансової інформації в публічних річних звітах емітентів, були отримані наступні результати:

1. На основі нормативних актів виділені ключові терміни, що підлягають обов'язковому оприлюдненню в річному звіті емітента.

2. Розроблена методика оцінки рівня розкриття нефінансової інформації по виділеним блокам на основі текстового аналізу.

3. Проведена оцінка розкриття інформації в публічній річній звітності видобувних компаній відповідно до законодавства РФ. Побудовано рейтинг розкриття інформації.

Наукова новизна. Уперше оцінюється розкриття обов'язкової інформації 120 публічних річних звітів 12 найбільших видобувних російських компаній, акції яких котируються на московській біржі з 2009 по 2018 рік. На основі нормативних актів виділені ключові терміни, що підлягають обов'язковому оприлюдненню в річному звіті емітента. Розроблена методика оцінки рівня розкриття нефінансової інформації за виділеними блоками на основі текстового аналізу. Проведена оцінка розкриття інформації в публічній річній звітності видобувних компаній відповідно до законодавства РФ.

Практична значимість. Розроблена бібліотека в середовищі R дозволить оцінити розкриття інформації в публічних річних звітах для будь-якого часового періоду.

Ключові слова: річний звіт, нефінансова звітність, видобувна промисловість, текстовий аналіз

Recommended for publication by L.I. Chernikova, Doctor of Economic Sciences. The manuscript was submitted 12.10.20. 